\author{
Békési Bertold, Ludányi Lajos
}

\title{
A HOMER AUTOTUNER ALKALMAZÁSA AZ AKTÍV SZENEK MIKROHULLÁMÚ VIZSGÁLATA SORÁN
}

DOI: $10.32560 /$ rk.2019.1.10

\begin{abstract}
A szerzők bemutatják az aktív szénre jellemzö mikrohullámú paramétereket, melyet az S-TEAM gyártó cég HOMER Autotuner STHT V1.4 típusú, ipari mikrohullámú rendszereknél alkalmazott automatikus mérö-és impedancia-illesztö berendezés segítségével mértek.
\end{abstract}

Kulcsszavak: aktív szén, Homer autotuner, mikrohullámú rendszerek, permittivitás, abszorpciós tényezö

\section{BEVEZETÉS}

A különböző nagyfrekvenciás (ezen belül a mikrohullámú) anyagvizsgálatok bizonyították, hogy a szénvegyületek és az elszenesedett anyagok nagymértékben abszorbeálják a mikrohullámú energiát. Ezért felvetődött annak gondolata, hogy a vizsgálatokhoz szükséges magas hömérsékletet és energiasűrüséget egy megfelelően méretezett, és kialakított berendezés segítségével és mikrohullámmal hozzuk létre.

Az aktív szén más, villamosam vezető tulajdonságú anyagokkal ellentétben másképpen viselkedik elektromágneses térben. Az aktív szén az általunk alkalmazott frekvencián kis értékü $\varepsilon$ ' - permittivitással és $\varepsilon "-$ abszorpciós tényezővel rendelkezik, amely nem indokolná a besugárzáskori intenzív hőmérséklet-emelkedéseket. Az ellentmondást a szén azon tulajdonsága oldja fel, hogy kis c - fajhővel, nagyságrendekkel kisebb $\rho$-fajlagos ellenállással (amely a negatív hőfoktényező miatt tovább csökken a hőmérséklet növekedésekor), és nagy $S$ vezetőképességgel rendelkezik.

Az anyagra jellemző mikrohullámú paramétereket, az S-TEAM gyártó cég HOMER Autotuner STHT V1.4 típusú, ipari mikrohullámú rendszereknél alkalmazott automatikus mérő-és impedancia-illesztő berendezésével mértük. [1][4][6].

\section{Az STHT 2,45 GHz-es Autotuner}

A HOMER sorozatú STHT 2.45-GHz-es Autotuner egy kompakt egységben integrálja a HOMER analizátort (automatikus impedancia és teljesítménymérő rendszer) és a HOMER Mototuner (háromszondás motoros tuner). Az R-26 (WR-340) hullámvezetőn alapuló rendszer a magnetron alapú mikrohullámú generátorok teljes müködési feltételei mellett müködik. Az elemző rész a reflexiós együttható nagyságát és fázisát, valamint a haladó, a visszavert és a disszipált teljesítményt és frekvenciát méri.

A Mototuner három mozgatómotoros tuning csonkból áll, amelyek a névleges tápvonali hullámhossz egynegyedének egymástól való távolságával vannak elhelyezve. 
A Tuner az Analyzer által mért adatokat használja az időben változó terhelések gyors automatikus impedancia illesztésére, pl. a félvezető gyártásban és más ipari alkalmazásokban, beleértve a plazmát is. A rendszert $\mathrm{CW}^{1}$, RECTIFIED és PULSED üzemmódokhoz tervezték (1. ábra) [1][4][5][6].

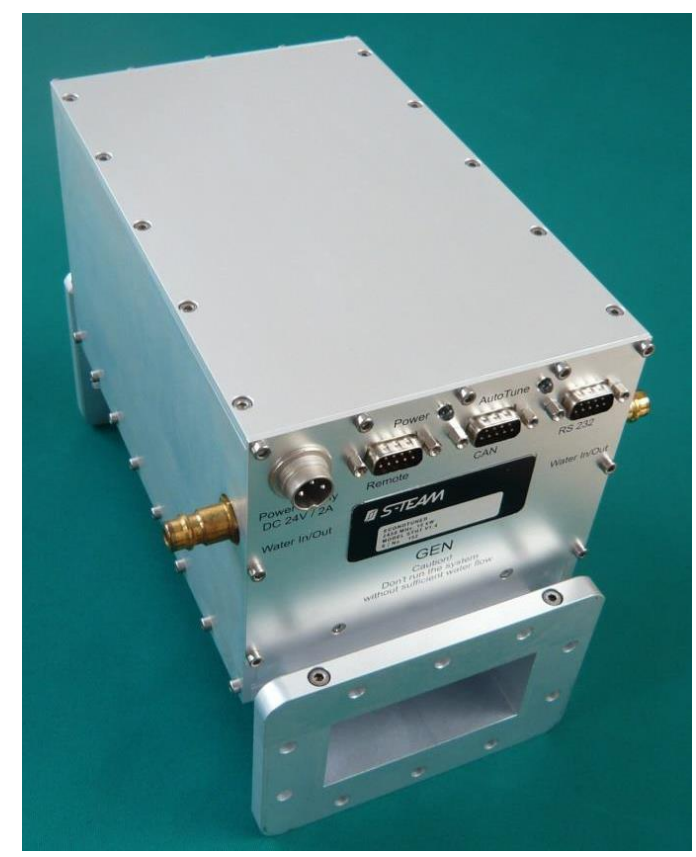

1. ábra A vízhütésű HOMER Autotuner STHT V1.4 [4]

Az STHT alkalmazásai:

† önállóan müködő, külső vezérlés nélküli alkalmazás;

$\neg$ személyi számítógépről vezérelve RS232 vagy CAN Bus interfészen keresztül;

$\downarrow$ LabVIEW környezetbe integrálva;

\section{Müködés elve}

A STHT elemző része a hatportos reflektométer (SPR2) elvén alapul. Az SPR alkalmas arra, hogy mérje a terhelés komplex reflexiós tényezőjét, valamint a haladó, a visszavert és a disszipált teljesítményeket. A rendszerbe egy frekvenciaszámláló is integrálódik [3].

Az ilyen típusú reflektométerek különösen alkalmasak ipari alkalmazásokhoz, ahol az on-line felügyelet és ellenőrzés teljes munkaidő mellett szükséges.

A tuner frekvencia-függő áramkört használ a szonda-pozíciók optimális beállításához, mely paramétereket a HOMER Analyzer méri és továbbítja a léptető motorok meghajtóihoz.

A prediktív algoritmusnak köszönhetően elkerülhetőek az időigényes próbaverziók és hibák optimalizálási sémái, amelyek lehetővé teszik a rosszul illeszkedő terhelések gyors és pontos illesztését.

A mintavétel módjai

Az STHT három mintavételi módot támogat:

\footnotetext{
${ }^{1}$ Continue wave $(\mathrm{CW})$ - folyomatos hullámú üzemmód

${ }^{2}$ six-port reflectometer (SPR)
} 
† A CW üzemmód: a moduláció nélküli mikrohullámú jelekre vonatkozik;

† Az RECTIFIED üzemmód: lassan pulzáló mikrohullámú jelekhez tervezték (maximum $400 \mathrm{~Hz}$ frekvenciáig). Az ilyen jelek jellemzőek az alacsony költségű tápegységek által müködtetett magnetronok esetében, amelyek egyszerü félhullámú vagy teljes hullámú egyenirányítót tartalmaznak.

† A PULSED üzemmód: (opcionális) elsősorban a gyors négyszögimpulzus-modulált mikrohullámú jelek leképezésére szolgál, különböző impulzusszélességekkel egészen 100 s-ig.

A Rectified és a Pulsed üzemmódokban biztosítva van a reflexiós koefficiensek és a teljesítmények pillanatnyi, valamint az átlagértékeik mérése. Az impedancia illesztés a komplex reflexiós tényező átlagértékén alapul [1][2][4][5][6].

\section{HomSoft vezérlési, vizualizációs és adatnaplózó szoftver}

Bár önálló rendszerként tervezték, a HomSoft vezérlési, vizualizációs és adatnaplózó szoftver jelentősen bővíti a rendszer képességeit (2. ábra). Az alapvető funkciók a következők [1]:

$\rightarrow$ Microsoft Windows ${ }^{\circledR}$ környezet

$\neg$ A komplex visszaverődési tényező pontos mérése és megjelenítése különböző formátumokban, többek között:

○ Magnitúdó (Mag);

○ Fázis (Phase);

○ Visszatérési veszteség (Return Loss);

○ VSWR (Feszültség Állóhullám-arány)

○ Poláris kijelző;

○ Smith Charts (Z-impedancia és Y-admittancia diagramok);

- Rieke-típusú diagram;

○ Haladó, visszavert és abszorbeált teljesítmény mérése és megjelenítése különböző formátumokban, beleértve a wattokat, a decibeleket, a teljesítmények százalékát;

○ A jelfrekvencia, a terhelési reflexiós koefficiens ( $\Gamma L$ ) és a különböző formátumok numerikus kiolvasása;

- A mérési sík önkényes elmozdítása (ГI, ГL);

○ A mért adatok mentése táblázatokba (szöveges fájlokba) vagy képekbe (BMP, GIF, JPG);

○ A mért mennyiségek összes vagy néhány időszakos adatnaplózása;

○ Több ablak, amelyek lehetővé teszik különböző mennyiségek egyidejü megfigyelését különböző formátumokban;

- A megjelenített görbék megjelenésének széles választéka;

- Az egyes feladatokhoz igazított teljes rendszerbeállítások tárolása és visszakeresése;

- Grafikus interfész a tuner-vezérléshez (a szondák kézi mozgatása, lépésenkénti/folyamatos önmüködés);

○ Elöírt forgatókönyv a szondák mozgatásához;

○ A DDE szerver opció lehetővé teszi egy másik Windows alkalmazás számára a mérési eredmények megosztását;

○ Kiterjedt online segítség [1][2][4][5][6]. 


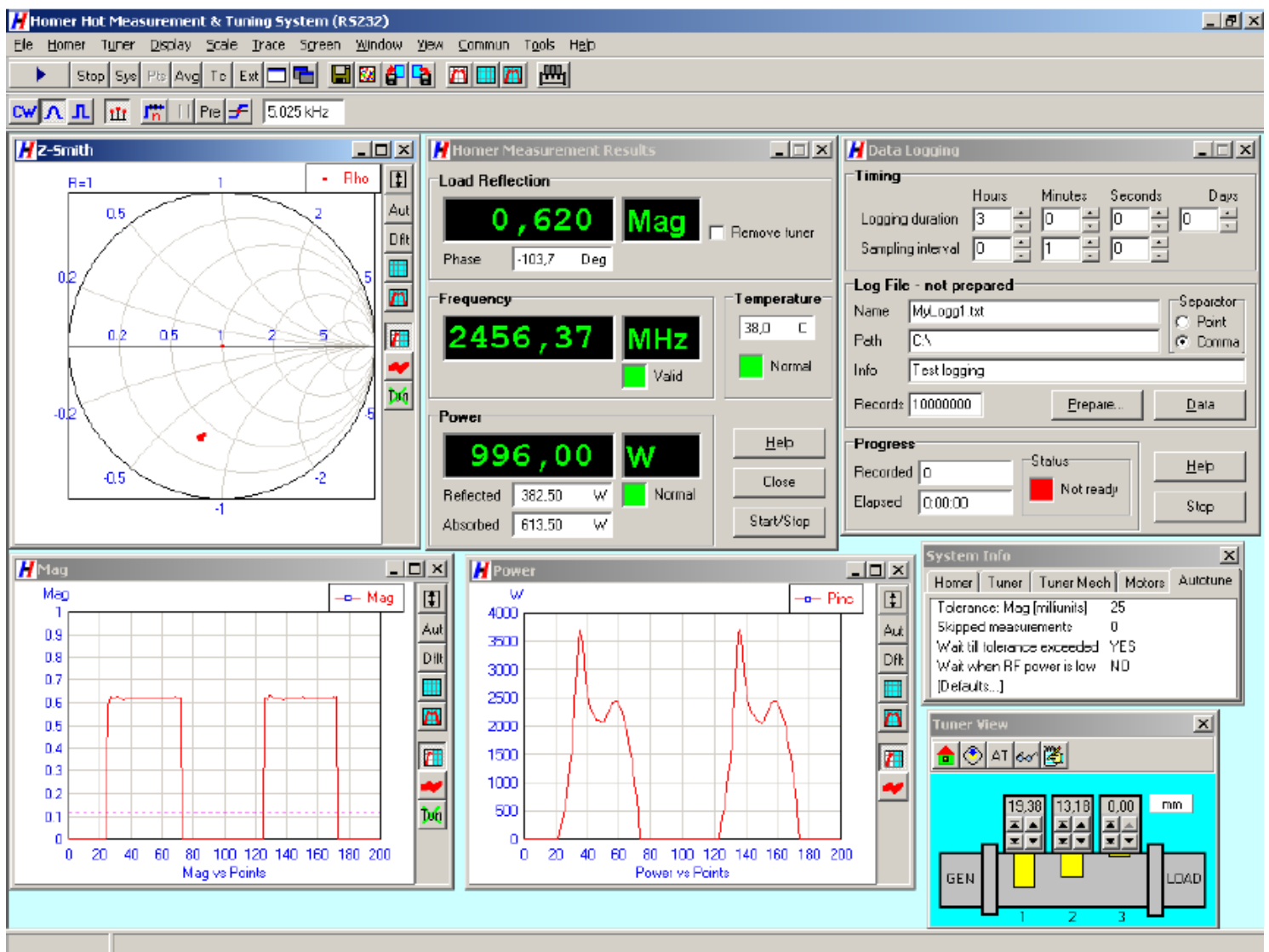

2. ábra A HomSoft kezelő felülete [4]

\begin{tabular}{|l|l|}
\hline Tápvonal típus & R-26 (WR-340) \\
\hline Karima típus & IEC \\
\hline Frekvenciatartomány & $2425-2475 \mathrm{MHz}$ \\
\hline Maximális bemeneti teljesítmény & $30 \mathrm{~kW}$ \\
\hline Minimális müködési teljesítmény & $100 \mathrm{~W}$ \\
\hline Dinamikus müködési teljesítmény tartomány & $20 \mathrm{~dB}$ \\
\hline Reflexiós koefficiens, mérési hiba & 0,05 \\
\hline Haladóteljesítmény mérési hiba (illesztett terhelés) & $\pm 5 \%$ \\
\hline Tápfeszültség & $24 \mathrm{~V} \pm 10 \%$ DC \\
\hline \multirow{2}{*}{ A csúcsáram-felvétel } & $2,5 \mathrm{~A}$ (normál motorok) \\
\cline { 2 - 2 } & $3 \mathrm{~A}$ (gyors motorok) \\
\hline Áramfelvétel & $1,3 \mathrm{~A}$ \\
\hline Interfész & RS232 vagy RS422, opcionálisan CAN busz \\
\hline A jelek mintavételének módjai & $\mathrm{CW}$, helyesbített, impulzusos \\
\hline Max. hullámzás CW módban & A csúcsérték 15\%-a \\
\hline A jelzés maximális ismétlési sebessége Rectified módban & $10 \mathrm{kHz}$ \\
\hline Min. impulzusszélesség pulzus üzemmódban & $100 \mu \mathrm{s}$ \\
\hline
\end{tabular}

1. táblázat A HOMER Autotuner STHT V1.4 müszaki paraméterei [4][5] 

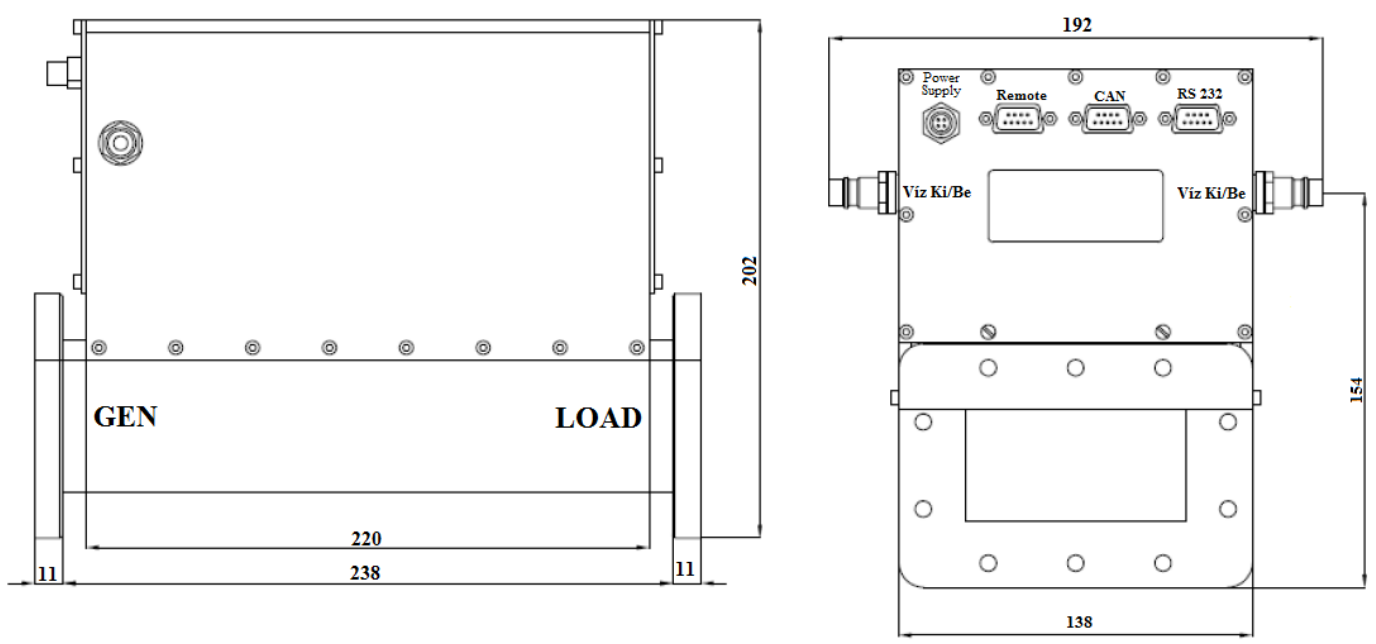

3. ábra A vízhütésű HOMER Autotuner STHT V1.4 alapméretei [4]

\section{Az aktív szén mikrohullámú vizsgálata}

Az aktív szén mikrohullámú vizsgálata különleges feladatot jelent. A mikrohullámú térben a felvett és a minta által átalakított energiát az elektromos térerő és frekvencia mellett - a szén dielektromos állandója határozza meg.

Az szén egy igen összetett anyagi rendszer. A mikrohullámú besugárzás során megváltozik az anyagi minőség, és ennek következtében a minta dielektromos állandója, és a felvett energia is megváltozik. Bonyolítja a helyzetet, hogy a minta dielektromos állandója még a hőmérséklet függvényében is nö, vagy csökken (például a víznél: $\varepsilon^{\prime}(T)=87-0,36^{*} T$, illetve $\varepsilon ”(T)=283 / T$ 1,17 alapján csökken) (2. táblázat).

\begin{tabular}{|c|c|c|c|c|c|c|c|c|c|}
\cline { 2 - 9 } \multicolumn{1}{c|}{} & \multicolumn{3}{c|}{$\mathbf{f = 2 , 4 5 ~ G H z}$} & \multicolumn{1}{c|}{$\boldsymbol{~}$} \\
\cline { 2 - 9 } \multicolumn{1}{c|}{} & $\boldsymbol{\varepsilon}^{\prime}$ & $\boldsymbol{\varepsilon}^{\prime \prime}$ & $\boldsymbol{t g} \boldsymbol{\Lambda}$ & $\boldsymbol{\Lambda}$ & $\boldsymbol{c}$ & $\boldsymbol{\rho}$ & $\boldsymbol{S}$ & $-\boldsymbol{\beta}$ & $\boldsymbol{T}$ \\
\hline Víz & 81 & 13 & 0,16 & 1,23 & 4,2 & 2,35 & 0,42 & $1,37 \cdot 10^{-5}$ & 20 \\
\hline Szén & 7,23 & 0,412 & 0,057 & 4,07 & 0,84 & $3-60 \cdot 10^{-5}$ & $\begin{array}{l}3,3 \cdot 10^{4} \\
1,6 \cdot 10^{3}\end{array}$ & $50 \cdot 10^{-5}$ & 20 \\
\hline
\end{tabular}

2. táblázat A víz és a szén villamossági szempontból vizsgált anyagi jellemzői ${ }^{3}$

A táblázat szénre jellemző anyagi paramétereiből, tehát kiemelendő néhány (a mikrohullámú hőfejlesztés szempontjából lényeges) adat, melyek a következők:

$\downarrow$ a szén permittivitása $\varepsilon_{\mathrm{r}}^{\prime}$;

$\downarrow$ a szén abszorpciós tényezője $\varepsilon_{\mathrm{r}}^{\prime \prime}$.

A két dielektromos adat viszonya megadja a $\operatorname{tg} \delta$ veszteségi tényezőt is: $\operatorname{tg} \delta=\varepsilon_{\mathrm{r}}^{\prime \prime} / \varepsilon_{\mathrm{r}}^{\prime}$. Mint ismeretes, a veszteséges közeggel kitöltött térben a síkhullám $Z_{T}$ hullámimpedanciája $(\Omega$-ban):

$$
\mathrm{Z}_{\mathrm{T}}=\frac{377}{\sqrt{\varepsilon_{\mathrm{r}}^{\prime}(\mathrm{T})}}\left[1-\frac{3}{8}[\operatorname{tg} \delta(\mathrm{T})]^{2}+\mathrm{j} \frac{1}{2} \operatorname{tg} \delta(\mathrm{T})\right]
$$

\footnotetext{
${ }^{3} \Lambda$ - hővezetési tényező; c - fajhő; $\rho$ - fajlagos ellenállás; $S$ - fajlagos elektromos vezetőképesség; - $\beta$ - hőfoktényező (negatív hőfoktényező)
} 
A fenti összefüggésből az is következik, hogy ha besugárzáskor növekszik a minta hőmérséklete, változik a minta permittivitásának és veszteségi tényezőjének értéke, amely megváltoztatja a veszteséges közeggel (a szénnel) töltött tér $\mathrm{Z}_{\mathrm{T}}$-impedanciáját, ez pedig megváltoztatja a viszszavert (reflektált) és ezzel együtt a minta belsejében abszorbeált energiát.

Az előzőekben leírtak elemzéséhez tekintsük a következő összefüggéseket:

$$
\begin{gathered}
\Gamma(\mathrm{T})=\sqrt{\frac{\mathrm{P}_{\mathrm{R}}(\mathrm{T})}{\mathrm{P}_{\mathrm{I}}}}=\frac{\sqrt{\varepsilon_{\mathrm{r}}^{\prime}(\mathrm{T})}-1}{\sqrt{\varepsilon_{\mathrm{r}}^{\prime}(\mathrm{T})}+1} \\
\mathrm{P}_{\mathrm{ABS}}(\mathrm{T})=\left(1-\Gamma^{2}(\mathrm{~T})\right) \mathrm{P}_{\mathrm{I}}
\end{gathered}
$$

ahol: $\mathrm{P}_{\mathrm{I}}$ - bemeneti, $\mathrm{P}_{\mathrm{R}}$ - reflektált, $\mathrm{P}_{\mathrm{ABS}}$ - abszorbeált teljesítmények

A reflexiós tényező a permittivitás függvényében látható a 4. ábrán:

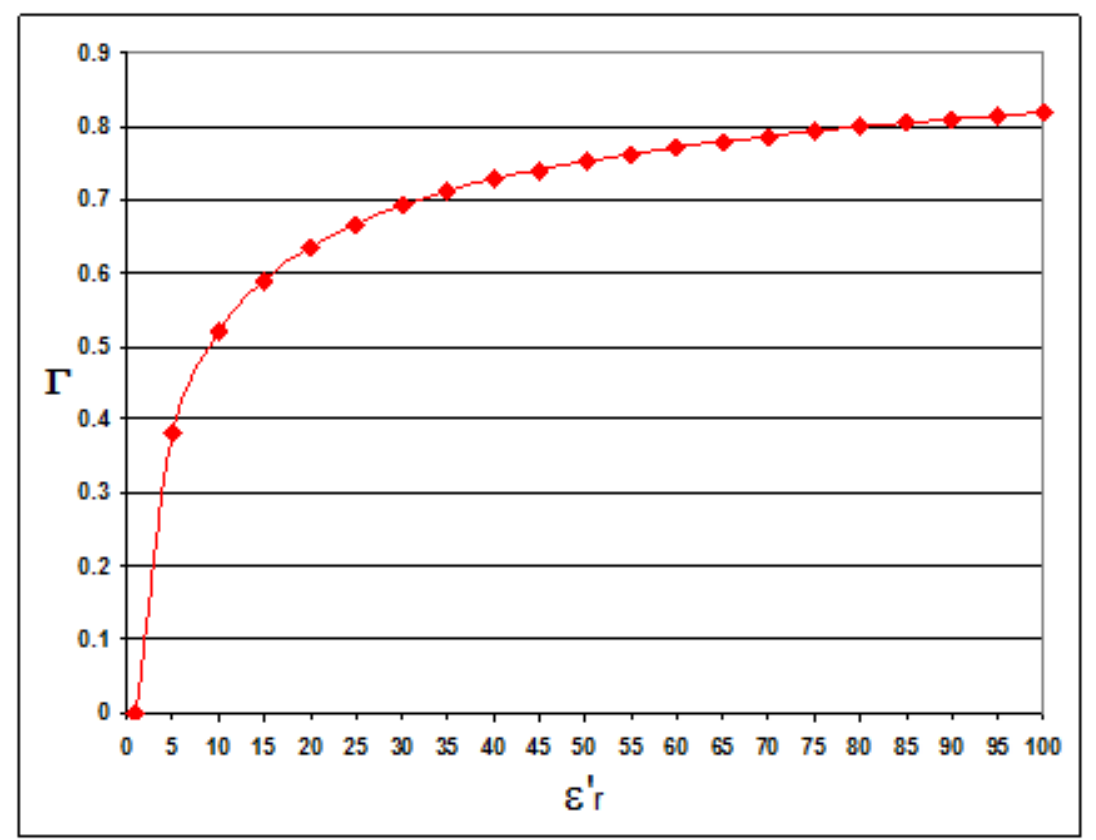

4. ábra A reflexiós tényező a permittivitás függvényében

A szénnek kis értékü dielektromos paraméterei vannak, viszonyítva a vízhez (lásd 1. táblázat), amely még kisebb reflexiót és még nagyobb abszorbeált teljesítményt biztosít.

Az aktív szén dielektromos paramétereit már közölték a különbözö kutatási jelentésekben és publikációkban ${ }^{4}$ (5. és 6. ábra), azonban ezek a vizsgálatok többnyire a különböző típusú aktív szenek dielektromos állandóinak frekvencia-függését vizsgálta, 100 MHz-5 GHz-es tartományban [7].

\footnotetext{
${ }^{4}$ Fatma Shkal, Susana Garcia Lopez, Daniel Slocombe, Adrian Porch Microwave Characterization of Activated Carbons, [Online]. Available: https://file.scirp.org/pdf/JCC_2017122809391812.pdf
} 


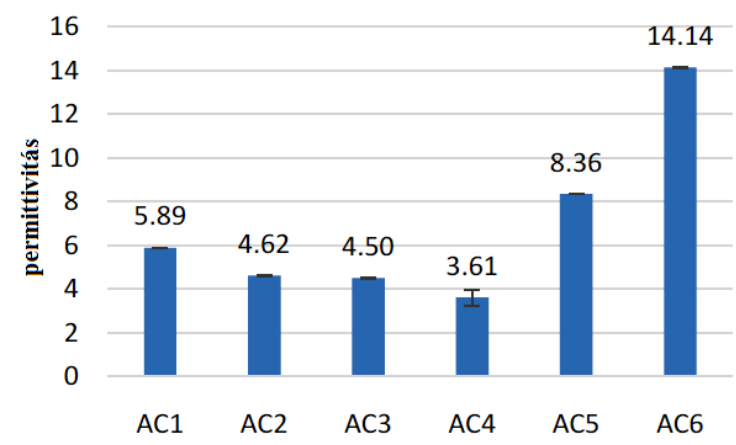

5. ábra Az aktív szenek $\varepsilon$ ' permittivitásai [7]

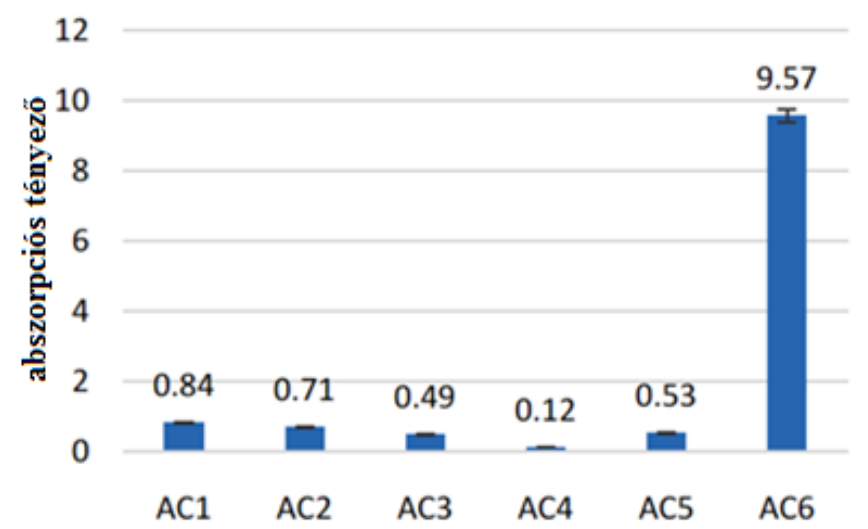

6. ábra Az aktív szenek $\varepsilon$ " abszorpciós tényezői [7]

A [7] publikációban közölt eredményekhez hasonlítottuk az általunk mért 100 g mennyiségü kompakt száraz aktív szén dielektromos állandójának értékét egy olyan mérési összeállítással, melyben a HOMER Autotuner mért adatait használtuk fel (7. ábra).

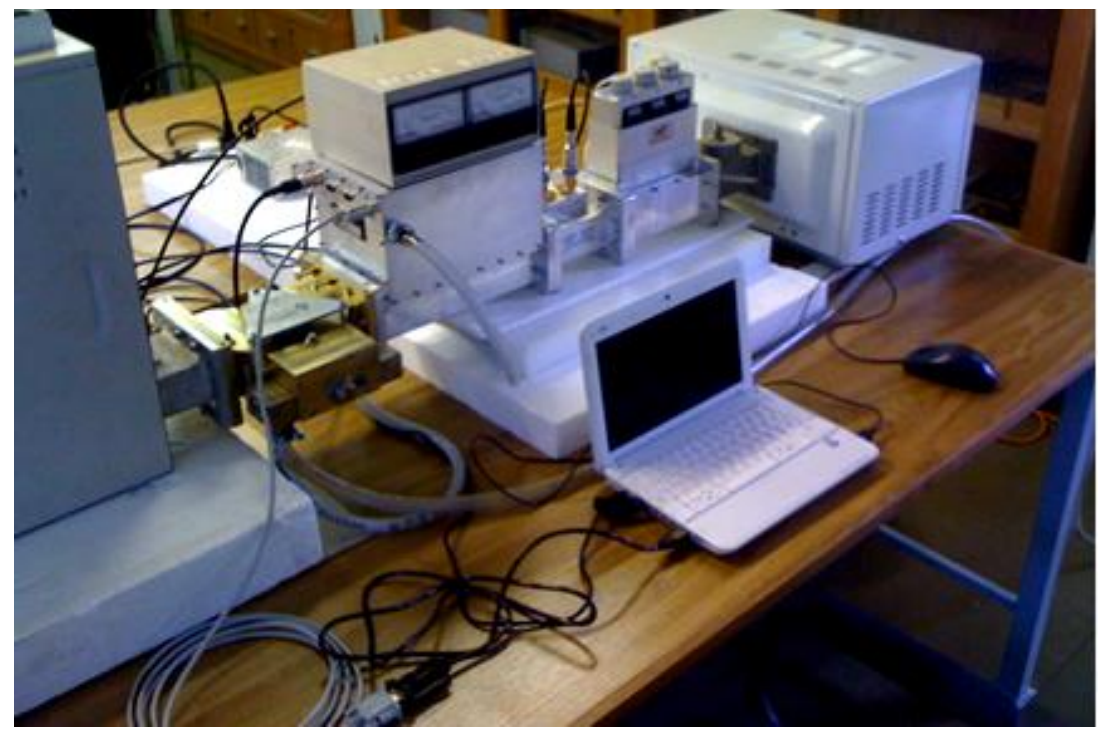

7. ábra Összeállítás az aktív szén dielektromos állandójának méréséhez

A rendszerrel mérhető volt a munkatérben elhelyezett töltet reflexiós tényezői, az állóhullámarányok, a terhelés fázistolásai, a haladó irányú, a reflektált és az abszorbeált teljesítmények értékei. A mért adatokat, az RS-porton keresztül beadva a vezérlő-jelfeldolgozó számítógépbe, kaptuk a következö grafikonokat (8., 9., 10. ábrák): 


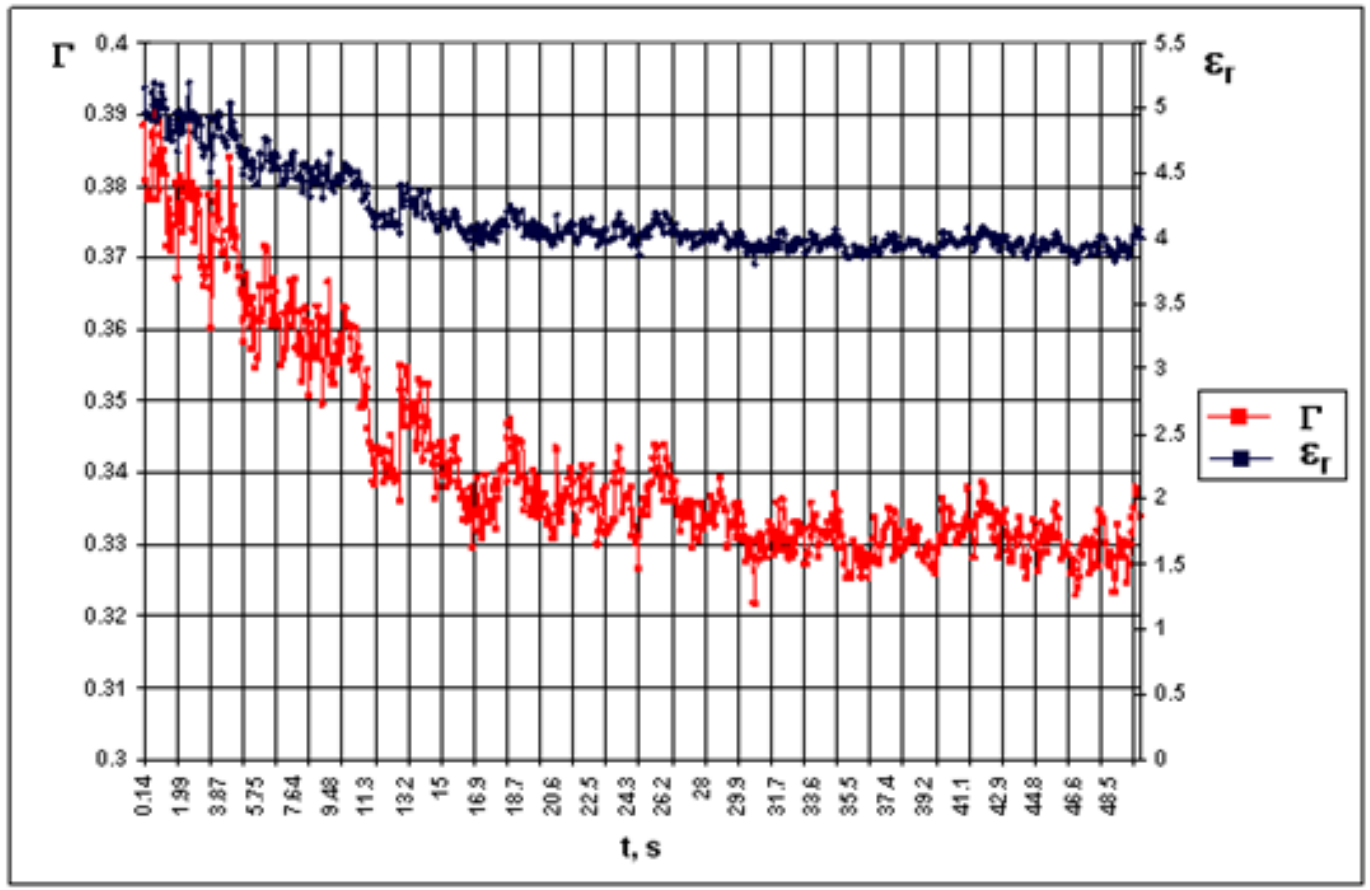

8. ábra Az aktív szén dielektromos állandójának és a reflexiós tényező értékének változása az 50s-os besugárzási idő függvényében

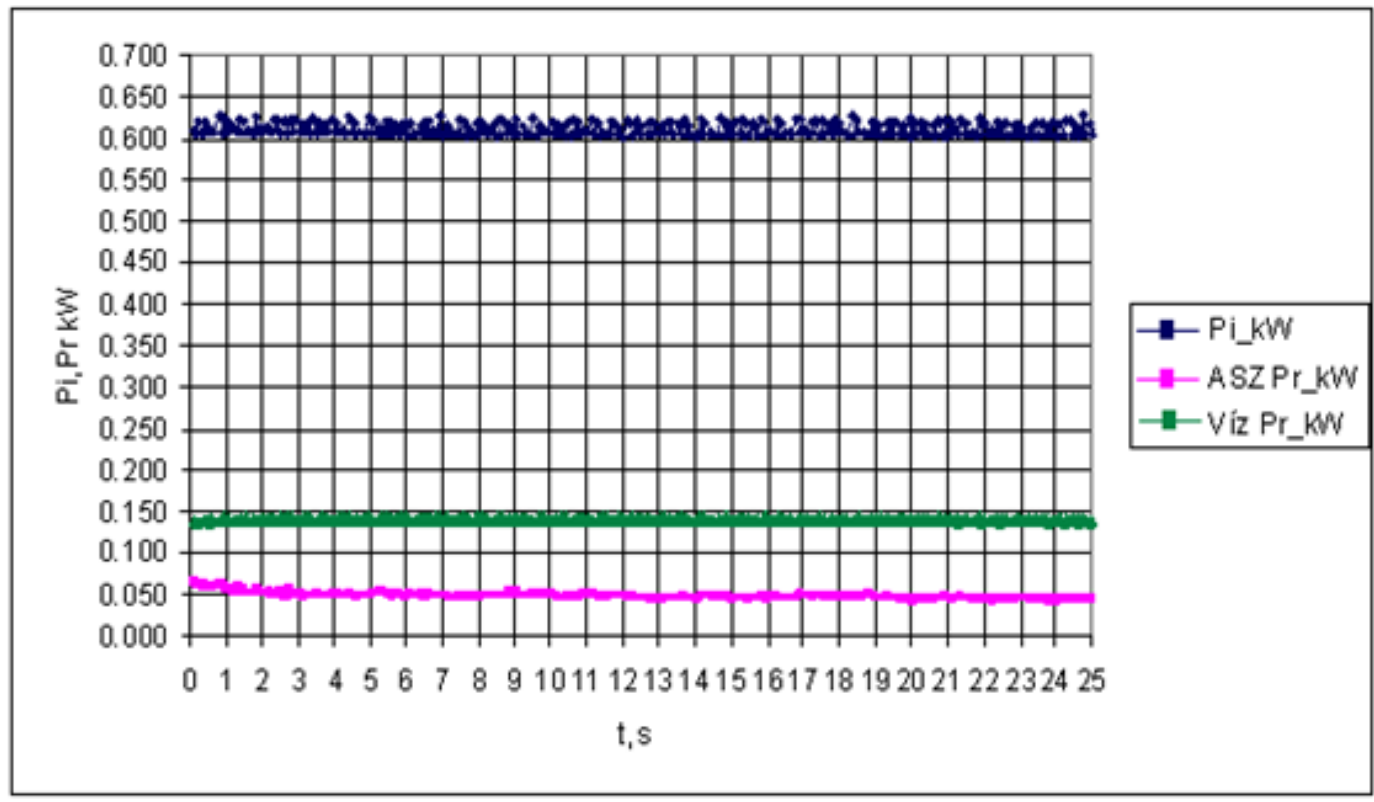

9. ábra Az aktív szén és az azonos mennyiségü víz 25s-os besugárzásakor mért reflektált teljesítmények idősorai 


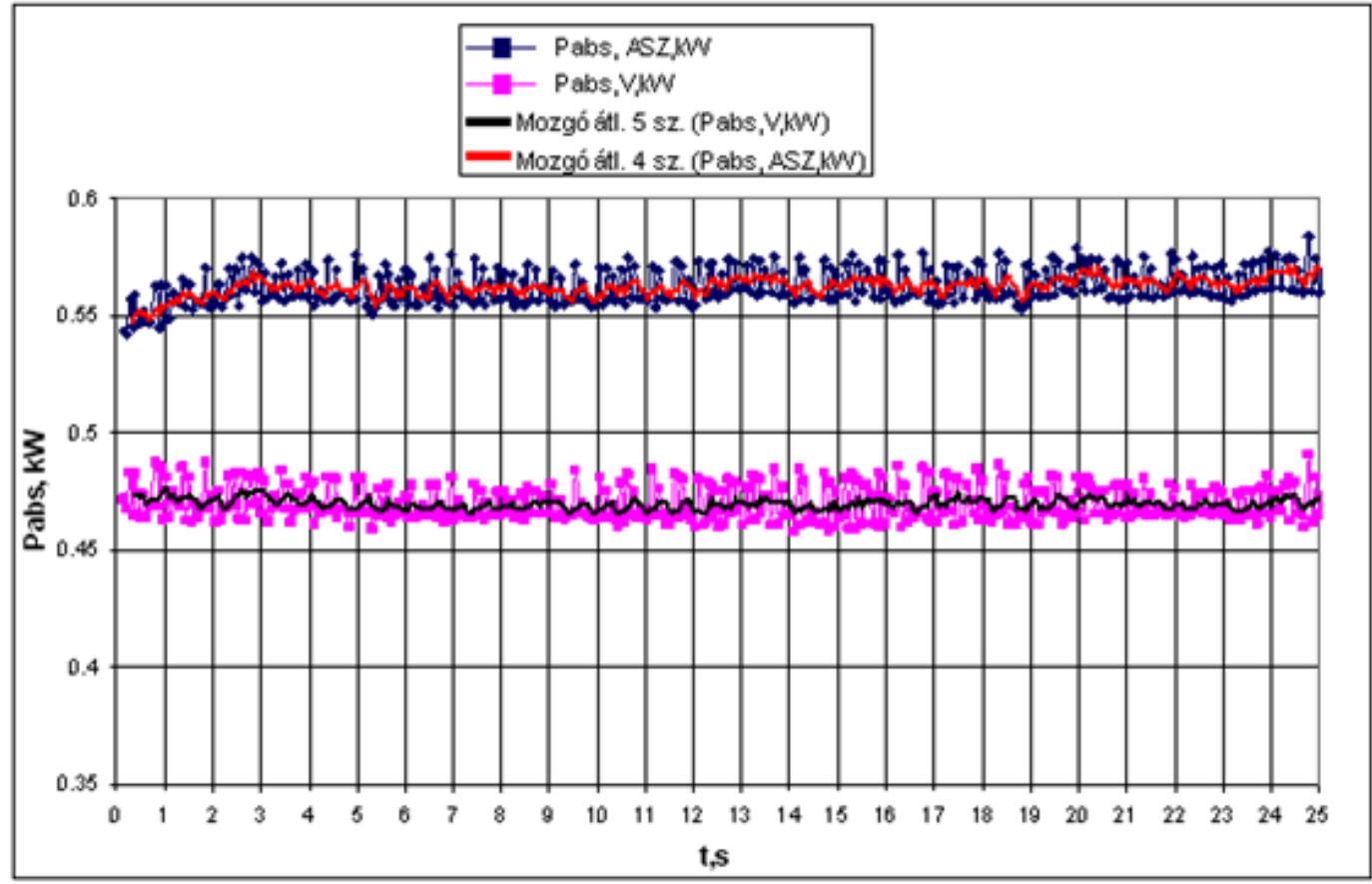

10. ábra A hővé alakuló abszorbeált teljesítmények aktív szénnél és víznél

\section{ÖSSZEFOGLALÁS}

A mért aktív szén dielektromos állandója (mind a permittivitásra, mind pedig az abszorpciós tényezőre vonatkozóan) a vízhez viszonyítva kis értékü, ezáltal kisebb a reflexiója, illetve nagyobb a teljesítményre vonatkoztatott abszorpciója. A mérések azonos kezdeti feltételek (mikrohullámú bemeneti teljesítmény, kezdeti hőmérséklet, tömeg, besugárzási idő) mellett voltak végrehajtva (11. ábra).

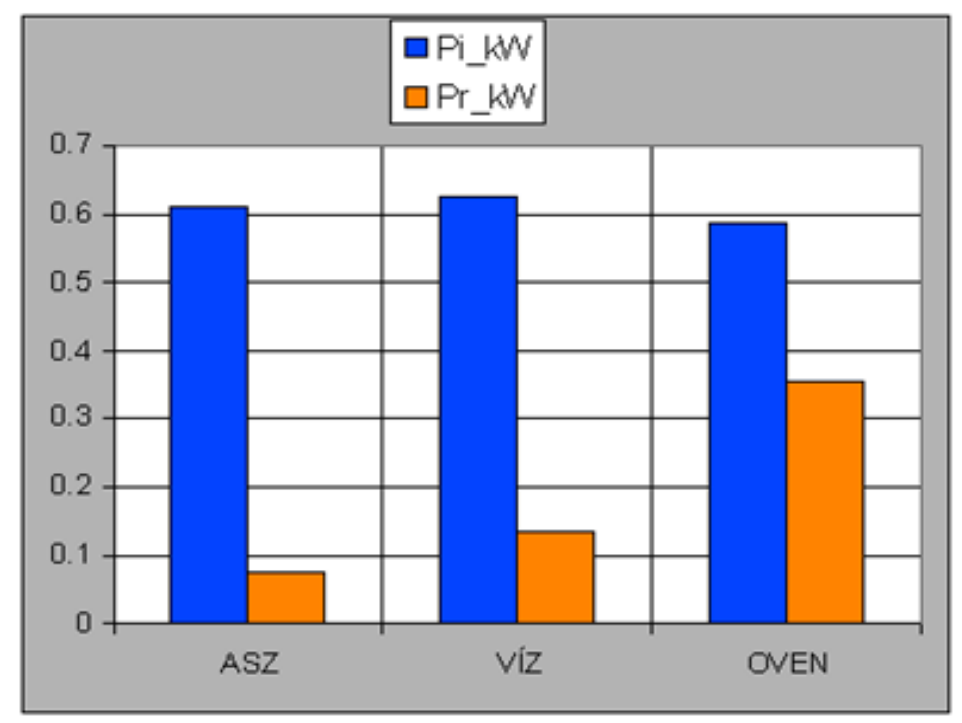

11. ábra. A reflektált és haladó irányú teljesítmények, különböző applikátor terheléseknél.

A mért adatokból meghatározhatjuk a különböző terhelések (ASZ - aktív szén, VÍZ, OVEN) viszszaverődési paramétereit, az SWR (Standing Wave Ratio - Állóhullámarány), Return Loss [dB] (Visszatérési veszteség), és Mismatch Loss [dB] (Illesztetlenségi veszteség) értékeit (12. ábra). 


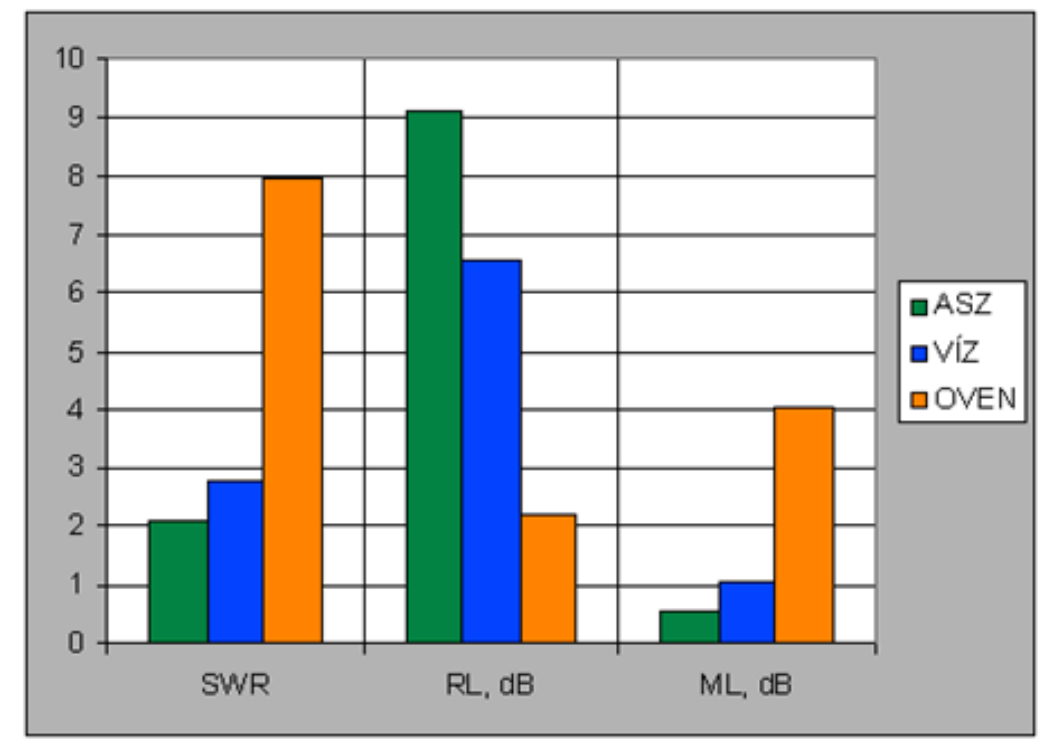

12. ábra A különböző terhelések visszaverődési paraméterei

A kapott eredmények kompakt száraz aktív szenekre vonatkoznak. Amennyiben a töltet nagy nedvesség-tartalmú, a nedves anyag dielektromos állandója is különbözni fog mind a száraz aktív szén mind pedig a víz dielektromos állandójától. Az ilyen kevert (mixelt) dielektromos állandó meghatározható például a Landau-Lifshitz, Looyenga összefüggése alapján:

$$
\begin{gathered}
\sqrt[3]{\varepsilon_{M}^{\prime}}=V_{V} \sqrt[3]{\varepsilon_{V}^{\prime}}+V_{A S Z} \sqrt[3]{\varepsilon_{A S Z}^{\prime}} \\
V_{V}+V_{A S Z}=1
\end{gathered}
$$

ahol: $V_{V}$ és $V_{A S Z}$ a víz és az aktív szén térfogat egységei.

$$
P_{d}=\omega \varepsilon_{0} \varepsilon_{r}^{\prime \prime} E^{2}=\omega \varepsilon_{0} \varepsilon_{r}^{\prime} \operatorname{tg} \delta E^{2}
$$

A (6) összefüggésből következik, hogy az abszorpciós tényező $\left(\varepsilon_{r}\right)$ minél nagyobb, annál nagyobb a hővé alakuló $P_{d}$ disszipált teljesítmény. Azonban a mérések, a kutatási jelentések mindegyike, az aktív szén abszorpciós tényezőjének kis értékét $(0,1-0,9)$ adják, ennek ellenére igen intenzív az aktív szén felmelegedése a mikrohullámú térben. Az ellentmondást a szén (az aktív szén), és a mikrohullám villamos terének kölcsönhatása oldja fel.

Ha a villamos áram homogén, mindenütt azonos hőmérsékletű vezetőben folyik (kivéve a szupravezetőket), akkor mindig keletkezik irreverzibilis hö-folyamat, a Joule-hatás (Joule-hö). A fejlődő hőt a környezet veszi fel, miközben magában a vezetőben növekszik a hőmérséklet.

Ha a vezető nem homogén, vagy nem egyenletes hőmérsékletű, akkor a Joule-hatás átfedi a reverzibilis hatásokat. Mivel ez utóbbiak az áramsürüséggel arányosak, a Joule-hatás pedig az áramsürüség négyzetével, a Joule-hő válik uralkodóvá, kivéve, ha az áram értéke rendkívül kicsi. A Joule-hő ezen kívül a vezető ellenállástól függ, és ennek törvényszerüsége makroszkopikus viszonylatban egyszerűen kimutatható.

Az eddigiek alapján nyilvánvaló, hogy a villamos térbe helyezett szénben (és az aktív szénben is) intenzív Joule-hő fejlődik, amely a szén kis értékü villamos ellenállásának, a kis értékü fajhőjének és a negatív hőfoktényezőjének köszönhető. 
A Joule-hő nemcsak U egyenfeszültségü táplálás esetén jön létre, hanem nagyfrekvenciás elektromágneses terekben is kialakul az anyag belsejében. Ezekben a terekben a mikrohullám E $[\mathrm{kV} / \mathrm{cm}]$ villamos térereje hat a szénre, és a térerő értéke függ a mikrohullámú generátor teljesítményétől, a munkatér (az applikátor) kialakításától, méretétől, az üzemi frekvencia és az ehhez kapcsolódó üzemi hullámhossz értékétől.

\section{FELHASZNÁLT IRODALOM}

[1] HOMER High Power Automatic Impedance/Power Analyzer and Matching Systems, [Online]. Available: http://www.s-team.sk/products/homer_autotuners.html

[2] Power Transmission Theory and Calculator [Online]. Available: http://www.s-team.sk/software_download.php

[3] Six-Port Measurement Technique: Theory and Applications [Online]. Available: http://www.s-team.sk/technical_info.php

[4] HOMER Autotuner ISM $2.45 \mathrm{GHz}$, [Online]. Available: http://www.s-team.sk/pdf/homer_autotuner_2450_R26.pdf

[5] Richardson Electronics. $2.45 \mathrm{GHz} 30 \mathrm{~kW}$ WR340 Autotuner, [Online]. Available: https://www.relltubes.com/filebase/en/src/Datasheets/2_45GHz-30kW-WR340-ECOTUNER.pdf

[6] User's Handbook Homer Hot Measurement and Tuning System S-TEAM Lab, [Online]. Available: http://www.s-team.sk/download/HomerHbook5004-58.pdf

[7] Fatma Shkal, Susana Garcia Lopez, Daniel Slocombe, Adrian Porch Microwave Characterization of Activated Carbons, [Online]. Available: https://file.scirp.org/pdf/JCC_2017122809391812.pdf DOI: https://doi.org/10.4236/jcc.2018.61012

\section{THE HOMER AUTONUNER USING IS AN ACTIVE CARBONS MICROWAVE TESTING}

The author presents the microwave characteristics of active carbon, measured by the S-TEAM manufacturer HOMER Autotuner STHT V1.4 using an automatic measuring and impedance matching device for industrial microwave systems.

Keywords: active carbon, HOMER Autotuner, microwave systems, permittivity, absorption factor

\begin{tabular}{ll}
\hline $\begin{array}{l}\text { Dr. Békési Bertold (PhD) } \\
\text { alezredes, egyetemi docens }\end{array}$ & Bertold Békési Dr. (PhD) \\
Nemzeti Közszolgálati Egyetem & Lieutenant Colonel, Associate Professor \\
Hadtudományi és Honvédtisztképző Kar & Fational University of Public Service \\
Katonai Repülö Intézet & Institute of Military Aviation \\
Fedélzeti Rendszerek Tanszék & $\begin{array}{l}\text { Department of Aircraft Onboard Systems } \\
\text { bekesi.bertold@ @uni-nke.hu }\end{array}$ \\
bekesi.bertold@uni-nke.hu & orcid.org/0000-0002-5709-789X \\
orcid.org/0000-0002-5709-789X & Lajos Ludányi Dr. (PhD) \\
\hline $\begin{array}{l}\text { Dr. Ludányi Lajos (PhD) } \\
\text { ny. alezredes, föiskolai tanár }\end{array}$ & ret. Lieutenant Colonel, College Professor \\
ludanyi.lajos@gmail.com & ludanyi.lajos@gmail.com \\
orcid.org/0000-0002-6677-5250 & orcid.org/0000-0002-6677-5250 \\
\hline
\end{tabular}

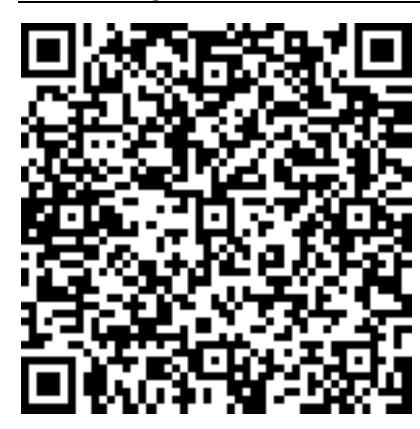

http://journals.uni-nke.hu/index.php/reptudkoz/article/view/337/39 
